\title{
NIPPLE SPARING MASTECTOMY: A LITERATURE REVIEW
}

\section{Mastectomia poupadora do complexo areolo-papilar: uma revisão da literatura}

\author{
Douglas de Miranda Pires¹, Eduardo José Souza da Fonseca1*, Carolina Nazareth Valadares², \\ Raffaela Levy Andrade1, Mariana dos Santos Nascimento1, Anna Maria Fonseca Albuquerque ${ }^{3}$
}

\section{ABSTRACT}

Introduction: The treatment of carcinoma in the early stages of breast cancer has achieved significant evolution in recent years. These developments culminated in the replacement of conventional mastectomy by more conservative techniques, such as nipple sparing mastectomy (NSM). This technique has been gaining space due to the fact that, in skin sparing mastectomy, the removal of the areola-papillary complex substantially compromises aesthetic results; despite recent and varied techniques of reconstructing of this complex, the dissatisfaction observed is of about $36 \%$ of the patients undergoing this procedure. Objective: Reviewing the literature about nipple sparing mastectomy of the areola-papillary complex, its oncological safety, selection criteria, surgical techniques and complications. Discussion: Oncologic safety is acceptable as long as matters such as selection criteria, low rate of complications and varied and feasible surgical techniques are in compliance. Conclusion: We found a current trend, in various institutions, to the standardization of the nipple sparing mastectomy for the treatment of early breast cancer cases. In order to achieve great results with this technique we need a multidisciplinary action between the breast surgeon, the clinical oncologist and the radiation therapy specialist. This technique shows excellent oncologic safety and low rates of complications when careful patient selection is associated with a surgeon's expertise. However, larger and longer follow-up series of patients undergoing NSM are still required.

KEYWORDS: Breast cancer; subcutaneous mastectomy; breast reconstruction.

\section{RESUMO}

Introdução: O tratamento do carcinoma nos estágios iniciais do câncer de mama tem alcançado evolução significativa nos últimos anos. Essa evolução culminou com a substituição da mastectomia convencional por técnicas mais conservadoras, como a mastectomia poupadora do complexo aréolo-papilar (MPCAP). Essa técnica vem ganhando espaço em virtude da constatação de que, na mastectomia poupadora de pele, a retirada do complexo aréolo-papilar (CAP) prejudica substancialmente os resultados estéticos e de que, apesar das recentes e variadas técnicas de reconstrução do complexo, o grau de insatisfação obtido é de cerca de $36 \%$ das pacientes submetidas a esse procedimento. Objetivo: Revisar a literatura a respeito da mastectomia poupadora do complexo aréolo-papilar, sua segurança oncológica, critérios de seleção, técnicas cirúrgicas e complicações. Discussão: Observou-se segurança oncológica aceitável desde que sejam respeitados os critérios de seleção, o baixo índice de complicações e as técnicas cirúrgicas variadas e factíveis. Conclusão: encontramos uma tendência atual, em várias instituições, de padronização da mastectomia poupadora do complexo aréolo-papilar para o tratamento dos casos iniciais do câncer de mama. Para que se alcance um resultado ótimo com essa técnica, é necessária uma ação multidisciplinar entre o cirurgião da mama, o oncologista clínico e o radioterapeuta. Essa técnica apresenta excelente segurança oncológica e baixas taxas de complicações quando uma criteriosa seleção dos pacientes, juntamente com a expertise do cirurgião, está associada. Entretanto, séries maiores e seguimento mais longo dos pacientes submetidos à MPCAP ainda se fazem necessários.

PALAVRAS-CHAVE: Câncer de mama; mastectomia subcutânea; mamoplastia.

Study carried out at Santa Casa de Belo Horizonte - Belo Horizonte (MG), Brazil.

'Santa Casa de Belo Horizonte - Belo Horizonte (MG), Brazil.

${ }^{2}$ Instituto de Ensino e Pesquisa, Santa Casa de Belo Horizonte - Belo Horizonte (MG), Brazil.

${ }^{3}$ Universidade Federal de Sergipe - Aracaju (SE), Brazil.

*Corresponding author: carolinanvaladares@gmail.com

Conflict of interests: nothing to declare.

Received on: 01/23/2017. Accepted on: 03/05/2018 


\section{INTRODUCTION}

The treatment of carcinoma in early stages of breast cancer have significantly evolved over the past few years. This improvement was initiated with the implementation of skin sparing mastectomy (SSM), which granted considerable aesthetic results to reconstructive breast surgery ${ }^{1}$.

Following this continuous replacement of conventional mastectomy techniques by more conservative ones, the nipple sparing mastectomy (NSM) was added to the arsenal of breast surgery, whose concept would be to extensively preserve the skin of the breast, including the areola-papillary complex (APC). This technique has gained space due to the fact that, in SSM, removing the areola-papillary complex substantially compromises the desired aesthetic results.

Despite recent and varied APC reconstruction techniques, either by local patching, dermopigmentation and/or skin or contralateral nipple donor grafts, various procedures are needed in order to achieve an acceptable aesthetic result ${ }^{2,3}$. Jabor et al. ${ }^{4}$ reported dissatisfaction of $36 \%$ of the patients submitted to APC. It should be noted that "The APC grants personality to the breast".

The first NSM ever described was carried out in 1960 by Freeman, who used this technique to extensive benign pathologies $^{5,6}$. However, only in the last few years has there been grater experience with NSM, due to its being indicated in the prophylaxis of breast cancer and the surgical treatment of initial cases of this pathology ${ }^{7-19}$. Despite some controversies regarding the risk of local recurrence, based on APC oncological involvement rates of about $58 \%{ }^{20}$ and the fact that the follow-up is too short in most clinical series, NSM has been considered safe for candidates to undergo conservative breast surgery. Currently, there is still no consensus on which patients would be selected for this technique; however, some parameters are suggested: tumor size less than $3 \mathrm{~cm}$, tumor at least $2 \mathrm{~cm}$ away from the APC, tumors not located in the central region of the breast, absence of cutaneous involvement and clinically negative axilla $a^{4,19-23}$.

This study was developed for a systematic review of the literature, aiming to evaluate: incision choice, oncologic safety, patient selection criteria, main complications and most used reconstruction techniques.

\section{METHOD}

A research was carried out in the main databases, Pubmed and Medline, as of March 2016. The terms used were: nipple sparing mastectomy, total skin sparing mastectomy, and subcutaneous mastectomy. The studies were selected based on the relevance and importance of the institutions where they were performed, as well as of the journals they were published in.

\section{DISCUSSION}

Incision choice: a wide variety of incisions has been described for $\mathrm{NSM}^{5,6,8-10,24-29}$. Endara et al. ${ }^{30}$, evaluating 48 studies on NSM, observed that the radial incision is the most used one - in about $46 \%$ of the NSM -, followed by periareolar incisions (27\%), in inframammary sulcus (20\%), wise pattern (4\%) and transareolar (percentage not available) (Figure 1 and Table 1).

Radial incision, which allows a technically safe and feasible mastectomy, in addition to being an excellent approach to
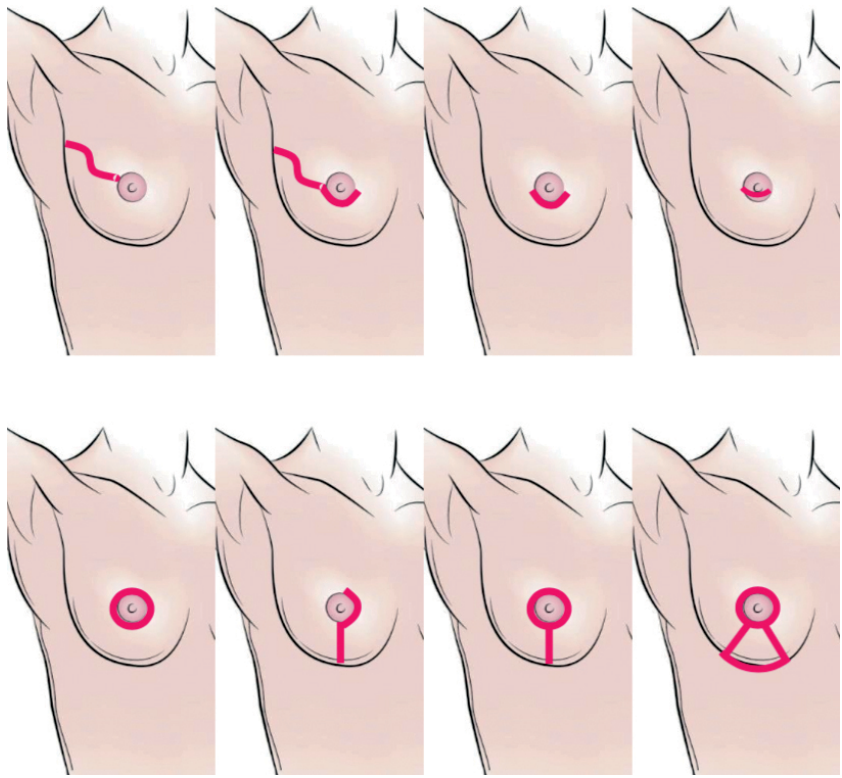

Figure 1. Types of incisions ${ }^{12}$.

Table 1. Type of incision and main advantages, disadvantages, areola-papillary complex (APC) necrosis rate and percentage of cases performed.

\begin{tabular}{|c|c|c|c|c|}
\hline Type of incision & Advantages & Disadvantages & APC necrosis & Performed in \\
\hline Radial & $\begin{array}{l}\text { Safe technique. } \\
\text { Excellent surgical access to the axilla. }\end{array}$ & $\begin{array}{l}\text { Scar in an aesthetically } \\
\text { unfavorable place. }\end{array}$ & $8 \%$ & $46 \%$ of the cases. \\
\hline Periareolar & Discreet scar, aesthetic result. & $\begin{array}{l}\text { Technical difficulty, more } \\
\text { indicated in small breasts. }\end{array}$ & $18 \%$ & $27 \%$ of the cases. \\
\hline $\begin{array}{l}\text { Inframammary } \\
\text { sulcus }\end{array}$ & Allows placement of prosthesis of any size. & $\begin{array}{l}\text { Difficult access to the upper } \\
\text { pole of the breast and axilla. }\end{array}$ & $9 \%$ & $20 \%$ of the cases. \\
\hline Wise pattern & $\begin{array}{l}\text { Reduction of cutaneous } \\
\text { envelope and dead space. } \\
\text { Extensive surgical access. }\end{array}$ & $\begin{array}{l}\text { Exposure of the prosthesis } \\
\text { in case of necrosis and } \\
\text { dehiscence. }\end{array}$ & $\begin{array}{l}\text { Data not } \\
\text { available. }\end{array}$ & $4 \%$ of the cases. \\
\hline Transareolar & Data not available. & High rates of APC necrosis. & $82 \%$ & Data not available. \\
\hline
\end{tabular}


axillary extensions and content ${ }^{16,31}$, presents APC complication rate of around $8 \%^{32}$ (Table 1). One of the cons would be the resulting scar in an aesthetically debatable position ${ }^{33}$.

The periareolar incision results in the best aesthetics, achieved by practically rendering the scar imperceptible over time. A negative aspect is its technical difficulty in most patients, being more often indicated in small breasts, with sufficient areolar diameter to allow satisfactory surgical access ${ }^{33}$. APC necrosis rates are observed around $18 \%$ (Table 1).

The incision in the inframammary sulcus ranks third among the most performed ones - approximately $20 \%^{11}$ (Table 1). It is feasible mainly in small breasts and allows for the placement of prosthesis of any size. It presents technical difficulty both in accessing the upper pole of the breast and also the axillary tail. In some occasions, the lateral extensions of the incision or a second incision in the axillary region is necessary to remove the sentinel lymph node. It presents APC necrosis in approximately $9 \%$ of the NSM.

The wise pattern mastopexy incision is chosen in about $4 \%$ of NSMs (Table 1). It is mainly indicated for bulky breasts, with moderate to severe ptosis. Its main advantages include reduction of the cutaneous envelope and the resulting dead space between the prosthesis and the skin. It also provides a wide surgical field with satisfactory access to all quadrants of the breast and armpit. Its main disadvantage is the possibility of necrosis and/or dehiscence of operative wounds exposing the prosthesis. In order to try and minimize this complication, the inferior pole of the decorticated breast has been used as a protection for scars. Another option would be the use of an acellular dermal matrix (ADM).

The transareolar incision is considered the riskiest one due to its APC necrosis rates in about $82 \%$ of surgeries (Table 1).

Oncologic safety and patient selection criteria: concerns regarding oncologic safety stems from concept that the ducts adjacent to the tumor may contain tumor cells, which would increase the rates of local recurrence ${ }^{34,35}$. The mean incidence of occult tumoral involvement of APC is estimated at 11.5\%, ranging from 0 to $53 \%^{36-38}$. Most studies state that NSM is safe for patients with small, non-central tumors, without multicentricity and in women undergoing risk-reducing surgeries ${ }^{19}$.

NSM is indicated for patients with breast cancer in initial clinical stages, without cutaneous involvement and/or inflammatory carcinoma ${ }^{6}$. The main inclusion criteria are based on: distance between the tumor and the APC of more than $2 \mathrm{~cm}$, tumors smaller than $3 \mathrm{~cm}$, and lack of APC involvement ${ }^{19}$.

Laronga et al..$^{39}$ found a higher rate of tumoral involvement of APC in patients with central (35\%) and multicentric (53\%) tumors. As oppose to that, a percentage of $2 \%$ of APC involvement was observed in patients with negative axilla and non-central tumors. Some studies did not find a relation between axillary status and APC involvement ${ }^{6,40}$.

Some series evaluated prior radiotherapy and chemotherapy and did not consider these conditions as contraindications ${ }^{41,42}$, even though other authors have observed a higher APC necrosis rate in previously irradiated patients.

A higher rate of APC tumoral involvement in patients with peritumoral lymphovascular invasion was found ${ }^{43-48}$, reaching $35.6 \%$ in some studies.

When the histological type of tumor and its histological grade were evaluated, results of studies were conflicting, raising the need for more elaborated series for the conclusion of these subjects.

As for the overexpression of the Human Epidermal Growth Factor Receptor - type 2 (HER2), three studies showed APC involvement rate of around $19.7 \%$, which was statistically significant ${ }^{43,48,49}$.

The influence of estrogen and progesterone receptors was evaluated by a few studies. The largest of which was carried out by Weidong at al.$^{48}$, demonstrating greater rates of APC involvement in negative estrogen and progesterone receptor tumors.

A meta-analysis performed by Zhang et al. ${ }^{50}$, evaluating 27 studies carried out between 1978 and 2014 with a total of 7,971 patients, showed that the most significant factors related to APC were: tumors $>5 \mathrm{~cm}$, positive axillary lymph nodes, tumor-APC distance $<2.5 \mathrm{~cm}$, stage III or IV, negative ER and PR, positive HER2 and carcinoma in situ.

Complications: despite having great advantages, NSM presents increased complications with operatory wound healing and necrosis ${ }^{5,19,23,27,38,44}$. The most frequent NSM complications are APC and cutaneous flaps necrosis. These complications have shown an important rate decrease due to the improvement of surgical techniques ${ }^{12,14,18,19}$. They currently have their incidence ranging from 0 to $19.5 \%^{10}$. Other complications found were hematoma and infection.

Reconstruction techniques: the main techniques for breast reconstruction in patients submitted to NSM are transitory or definitive implants and autologous flaps.

The criteria used to choose the type of reconstruction may be divided, in NSM cases, into: factors related to the tumor location and proximity to the skin and the APC and the size of the tumor - and factors related to the patient - smoking, diabetes, body mass index (BMI), breast size, degree of ptosis, areola size and the patient's desire. Experience of the surgeon and the team should also be noted.

With the evolution of implants and expanders, the use of these materials in breast reconstruction is ever-widening. Endara et al. ${ }^{30}$, in a recent review, observed from 6,615 NSM procedures, the occurrence of 2,373 (45.5\%) reconstructions with expander followed by definitive implant, 2,126 (40.7\%) reconstructions with definitive implant at once and 719 (13.8\%) reconstructions with autologous flaps.

Another option is the use of expansive prostheses with the purpose of reconstructing at once, thus favoring postoperative adjustments in implant volume and contralateral symmetry ${ }^{17,26}$.

The main autologous flaps used are: large dorsal flap, transverse rectus abdominis muscle flap (TRAM), free rectus abdominis 
muscle flap and free gluteal muscle flap. Negative factors are: morbidity in the donation area, surgeries demanding greater expertise of the surgeon and the team, and longer length of surgery. Good tolerability to radiotherapy and a satisfactory longterm outcome - similar to those of non-operated breasts - are the main favorable points.

\section{CONCLUSION}

NSM has gained space as treatment of choice along with the highest number of breast cancer diagnoses in initial stages, with the objective of satisfactory aesthetic results. A current trend is seen in several institutions towards the acceptance of this technique when risk-reducing mastectomies are desirable and also when it is necessary to treat breast cancer. In order to achieve optimal results with this technique, a multidisciplinary action is required of the breast surgeon, the oncologist clinician and the radiotherapist. This technique presents excellent oncologic safety and low complication rates when careful selection of patients associated with the surgeon's expertise is ensured. However, larger series and longer-term follow-ups of patients submitted to NSM are still necessary.

\section{REFERENCES}

1. Toth BA, Lappert P. Modified skin incisions for mastectomy: the need for plastic surgical input in preoperative planning. Plast Reconstr Surg. 1991;87:1048-53.

2. Kroll SS, Ames F, Singletary SE, Schusterman MA. The oncologic risks of skin preservation at mastectomy when combined with immediate reconstruction of the breast. Surg Gynecol Obstet. 1991;172:17-20.

3. Singletary SE. Skin-sparing mastectomy with immediate breast reconstruction: the M. D. Anderson Cancer Center experience. Ann Surg Oncol. 1996;3:411-6.

4. Jabor MA, Shayani P, Collins DR, Karas T, Cohen BE. Nippleareola reconstruction: satisfaction and clinical determinants. Plast Reconstr Surg. 2002;110:457-63; discussion 464-5.

5. Freeman BS. Subcutaneous mastectomy for benign breast lesions with immediate or delayed prosthetic replacement. Plast Reconstr Surg Transplant Bull. 1962;30:676-82.

6. Garcia-Etienne CA, Cody III HS, Disa JJ, Cordeiro P, Sacchini V. Nipple-sparing mastectomy: initial experience at the Memorial Sloan-Kettering Cancer Center and a comprehensive review of literature. Breast J. 2009;15:440-9. http://doi.org/10.1111/j.1524-4741.2009.00758.x

7. Boneti C, Yuen J, Santiago C, Diaz Z, Robertson Y, Korourian $\mathrm{S}$, et al. Oncologic safety of nipple skin-sparing or total skinsparing mastectomies with immediate reconstruction. J Am Coll Surg. 2011;212:686-93; discussion 693-95. http://doi. org/10.1016/j.jamcollsurg.2010.12.039

8. Caruso F, Ferrara M, Castiglione G, Trombetta G, De Meo L, Catanuto G, et al. Nipple sparing subcutaneous mas- tectomy: sixty-six months follow-up. Eur J Surg Oncol. 2006;32:937-40. https://doi.org/10.1016/j.ejso.2006.05.013

9. Chen CM, Disa JJ, Sacchini V, Pusic AL, Mehrara BJ, GarciaEtienne CA, et al. Nipple-sparing mastectomy and immediate tissue expander/implant breast reconstruction. Plast Reconstr Surg. 2009;124:1772-80. https://doi.org/10.1097/ PRS.0b013e3181bd05fd

10. De Alcantara Filho P, Capko D, Barry JM, Morrow M, Pusic A, Sacchini VS. Nipple-sparing mastectomy for breast cancer and risk-reducing surgery: the Memorial Sloan-Kettering
Cancer Center experience. Ann Surg Oncol. 2011;18:3117-22. https://doi.org/10.1245/s10434-011-1974-y

11. Garcia-Etienne CA, Borgen PI. Update on the indications for nipple-sparing mastectomy. J Support Oncol. 2006;4:225-30.

12. Jensen JA, Orringer JS, Giuliano AE. Nipple-sparing mastectomy in 99 patients with a mean follow-up of 5 years. Ann Surg Oncol. 2011;18:1665-70. https://doi.org/10.1245/s10434-010-1475-4

13. Komorowski AL, Zanini V, Regolo L, Carolei A, Wysocki WM, Costa A. Necrotic complications after nipple- and areolasparing mastectomy. World J Surg. 2006;30:1410-3. https:// doi.org/10.1007/s00268-005-0650-4

14. Regolo L, Ballardini B, Gallarotti E, Scoccia E, Zanini V. Nipple sparing mastectomy: an innovative skin incision for an alternative approach. Breast. 2008;17:8-11. https://doi. org/10.1016/j.breast.2007.07.040

15. Sacchini V, Pinotti JA, Barros AC, Luini A, Pluchinotta A, Pinotti M, et al. Nipple-sparing mastectomy for breast cancer and risk reduction: oncologic or technical problem? J Am Coll Surg. 2006;203:704-14. https://doi.org/10.1016/j. jamcollsurg.2006.07.015

16. Stolier AJ, Sullivan SK, Dellacroce FJ. Technical considerations in nipple-sparing mastectomy: 82 consecutive cases without necrosis. Ann Surg Oncol. 2008;15:1341-7. https://doi. org/10.1245/s10434-007-9753-5

17. Munhoz AM, Aldrighi C, Montag E, Arruda EG, Aldrighi JM, Filassi JR, et al. Periareolar skin-sparing mastectomy and latissimus dorsi ap with biodimensional expander implant reconstruction:surgicalplanning, outcome, and complications. Plast Reconstr Surg. 2007;119:1637-149; discussion 1650-2. https://doi.org/10.1097/01.prs.0000246406.68739.e4

18. Nava MB, Cortinovis U, Ottolenghi J, Riggio E, Pennati A, Catanuto G, et al. Skin-reducing mastectomy. Plast Reconstr Surg. 2006;118:603-10;discussion 611-3. https://doi. org/10.1097/01.prs.0000233024.08392.14

19. Tokin C, Weiss A, Wang-Rodriguez J, Blair SL. Oncologic safety of skin-sparing and nipple-sparing mastectomy: a discussion and review of the literature. Int J Surg Oncol. 2012;2012:921821. https://doi.org/10.1155/2012/921821 
20. Cense HA, Rutgers EJ, Lopes Cardozo M, Van Lanschot JJ. Nipple-sparing mastectomy in breast cancer: A viable option? Eur J Surg Oncol. 2001;27:521-6. https://doi.org/10.1053/ ejso.2001.1130

21. Mosahebi A, Ramakrishnan V, Gittos M, Collier J. Aesthetic outcome of different techniques of reconstruction following nipple-areola-preserving envelope mastectomy with immediate reconstruction. Plast Reconstr Surg. 2007;119:796803. https://doi.org/10.1097/01.prs.0000251999.52374.09

22. Radovanovic Z, Radovanovic D, Golubovic A, Ivkovic-Kapicl T, BokorovB, Mandic A.Early complications afternipple-sparing mastectomy and immediate breast reconstruction with silicone prosthesis: Results of 214 procedures. Scand J Surg. 2010;99:115-8. https://doi.org/10.1177/145749691009900302

23. Spear SL, Willey SC, Feldman ED, Cocilovo C, Sidawy M, AlAttar A, et al.Nipple-sparing mastectomy for prophylactic and therapeutic indications. Plast Reconstr Surg. 2011;128:100514. https://doi.org/10.1097/PRS.0b013e31822b6456

24. Blechman KM, Karp NS, Levovitz C, Guth AA, Axelrod DM, Shapiro RL, et al. The lateral inframammary fold in- cision for nipple-sparing mastectomy: outcomes from over 50 immediate implant-based breast reconstructions. Breast J. 2013;19:31-40. https://doi.org/10.1111/tbj.12043

25. Crowe JP, Patrick RJ, Yetman RJ, Djohan R. Nipple-sparing mastectomy update: One hundred forty-nine procedures and clinical outcomes. Arch Surg. 2008;143:1106-10;discussion 1110. https://doi.org/10.1001/archsurg.143.11.1106

26. Munhoz AM, Aldrighi C, Montag E, Arruda E, Aldrighi JM, Filassi JR, et al. Optimizing the nipple-areola sparing mastectomy with double concentric periareolar incision and biodimensional expander-implant reconstruction: aesthetic and technical renements. Breast. 2009;18:356-67. https://doi. org/10.1016/j.breast.2009.09.008

27. Munhoz AM, Aldrighi CM, Montag E, Arruda EG, Aldrighi JM, Gemperli R, et al. Clinical outcomes following nippleareola-sparing mastectomy with immediate implant-based breast reconstruction: a 12-year experience with an analysis of patient and breast-related factors for complications. Breast Cancer Res Treat. 2013;140:545-55. https://doi.org/10.1007/ s10549-013-2634-7

28. Rivolin A, Kubatzki F, Marocco F, Martincich L, Renditore S, Maggiorotto F, et al. Nipple-areola complex sparing mastectomy with periareolar pexy for breast cancer patients with moderately ptotic breasts. J Plast Reconstr Aesthet Surg. 2012;65:296-303. https://doi.org/10.1016/j.bjps.2011.09.023

29. Salibian AH, Harness JK, Mowlds DS. Inframammary approach to nipple-areola-sparing mastectomy. Plast Reconstr Surg. 2013;132:700e-8e. https://doi.org/10.1097/ PRS.0b013e3182a4d64f

30. Endara M, Chen D, Verma K, Nahabedian MY, Spear SL. Breast reconstruction following nipple-sparing mastectomy: a systematic review of the literature with pooled analysis. Plast Reconstr Surg. 2013;132:1043-54. https://doi.org/10.1097/ PRS.0b013e3182a48b8a

31. Yang SJ, Eom JS, Lee TJ, Ahn SH, Son BH. Recipient vessel selection in immediate breast reconstruction with free abdominal tissue transfer after nipple-sparing mastectomy. Arch Plast Surg. 2012;39:216-21. https://dx.doi. org/10.5999\%2Faps.2012.39.3.216

32. Chung AP, Sacchini V. Nipple-sparing mastectomy: where are we now? Surg Oncol. 2008;17:261-6. https://dx.doi. org/10.1016/j.suronc.2008.03.004

33. Sahin I, Isik S, Alhan D, Yıldız R, Aykan A, Ozturk E. Onestaged silicone implant breast reconstruction following bilateral nipple-sparing prophylactic mastectomy in patients at high-risk for breast cancer. Aesthetic Plast Surg. 2013;37:30311. https://dx.doi.org/10.1007/s00266-012-0044-6

34. Patani N, Mokbel K. Oncological and aesthetic considerations of skin-sparing mastectomy. Breast Cancer Res Treat. 2008;111:391-403. https://doi.org/10.1007/s10549-007-9801-7

35. Singletary SE, Robb GL. Oncologic safety of skin-sparing mastectomy. Ann Surg Oncol. 2003;10:95-7.

36. Andersen JA, Pallesen RM. Spread to the nipple and areola in carcinoma of the breast. Ann Surg. 1979;189:367-72.

37. Vyas JJ, Chinoy RF, Vaidyat JS. Prediction of nipple and areola involvement in breast cancer. Eur J Surg Oncol. 1998;24:15-6.

38. Simmons RM, Brennan M, Christos P, King V, Osborne M. Analysis of nipple/areolar involvement with mastectomy: Can the areola be preserved? Ann Surg Oncol. 2002;9:165-8.

39. Laronga C, Kemp B, Johnston D, Robb GL, Singletary SE. The incidence of occult nipple-areola complex involvement in breast cancer patients receiving a skin-sparing mastectomy. Ann Surg Oncol. 1999;6:609-13.

40. PetitJY, Veronesi U, Orecchia R, Rey P, Didier F, Giraldo A, et al. The nipple-sparing mastectomy: Early results of a feasibility study of a new application of perioperative radiotherapy (ELIOT) in the treatment of breast cancer when mastectomy is indicated. Tumori. 2003;89:288-91.

41. Blechman KM, Karp NS, Levovitz C, Guth AA, Axelrod $\mathrm{DM}$, Shapiro RL, et al. The lateral inframammary fold incision for nipple-sparing mastectomy: Outcomes from over 50 immediate implant-based breast reconstructions. Breast J. 2013;19:31-40. https://doi.org/10.1111/tbj.12043

42. Wang J, Xiao X, Wang J, Iqbal N, Baxter L, Skinner KA, et al. Predictors of nipple-areolar complex involvement by breast carcinoma: Histopathologic analysis of 787 consecutive therapeutic mastectomy specimens. Ann Surg Oncol. 2012;19:1174-80. https://doi.org/10.1245/s10434-011-2107-3

43. Brachtel EF, Rusby JE, Michaelson JS, Chen LL, Muzikansky A, Smith BL, et al. Occult nipple involvement in breast cancer: Clinicopathologic findings in 316 consecutive mastectomy specimens. J Clin Oncol. 2009;27:4948-54. https://doi. org/10.1200/JCO.2008.20.8785

44. Gulben K, Yildirim E, Berberoglu U. Prediction of occult nipple-areola complex involvement in breast cancer patients. Neoplasma. 2009;56:72-5.

45. Vyas JJ, Chinoy RF, Vaidyat JS. Prediction of nipple and areola involvement in breast cancer. Eur J Surg Oncol. 1998;24:15-6.

46. Khan K, Chakraborti S, Mondal S. Morphological predictors of nipple areola involvement in malignant breast tumors. Indian J Pathol Microbiol. 2010;53:232-7. https://doi. org/10.4103/0377-4929.64329 
47. Vlajcic Z, Zic R, Stanec S, Lambasa S, Petrovecki M, Stanec Z. Nipple-areola complex preservation: Predictive factors of neoplastic nipple-areola complex invasion. Ann Plast Surg. 2005;55:240-4.

48. Weidong L, Wang S, Guo X, Lang R, Fan Y, Gu F, et al. Nipple involvement in breast cancer: Retrospective analysis of 2323 consecutive mastectomy specimens. Int J Surg Pathol. 2011;19:328-34. https://doi. org/10.1177/1066896911399279
49. Pirozzi PR, Rossetti C, Carelli I, Ruiz CA, Pompei LM, Piato S. Clinical and morphological factors predictive of occult involvement of the nipple-areola complex in mastectomy specimens. Eur J Obstet Gynecol Reprod Biol. 2010;148:177-81. https://doi.org/10.1016/j.ejogrb.2009.10.021

50. Zhang H, Li Y, Moran MS, Haffty BG, Yang Q. Predictive factors of nipple involvement in breast cancer: a systematic review and meta-analysis. Breast Cancer Res Treat. 2015;151:239-49. https://doi.org/10.1007/s10549-015-3385-4 